\title{
The Increased Learning Effectiveness Through Strengthening Organizational Climate and Pedagogical Competency
}

\author{
Hendarman ${ }^{1,2, *}$ \\ ${ }^{1}$ Postgraduate, ${ }^{2}$ Head of Character Building Center \\ ${ }^{1}$ Pakuan University, ${ }^{2}$ The Ministry of Education and Culture \\ ${ }^{1}$ Bogor, Indonesia, ${ }^{2}$ Jakarta, Indonesia \\ *hendarman@pakuan.com
}

\author{
Virni Sahna Saefi \\ Teacher \\ SDN Kukupu \\ Bogor, Indonesia
}

\author{
Yuyun E. Patras \\ Postgraduate \\ Pakuan University \\ Bogor, Indonesia
}

\begin{abstract}
This research focussed on how organizational climate and pedagogical competency affect learning effectiveness of government teachers within primary school in the area of the Tanah Sereal sub-district. In this area, it seems that government teachers have yet to make use the two variables in improving their learning effectiveness. The research employed 107 sampled teachers using proportional random sampling and is analysed using correlation. Hypothetical testing using parametric statistical analysis in the form of simple and multiple linear regression analysis, simple and multiple correlation analysis, and partial analysis with significant levels $\alpha=0.01$ and $\alpha=0.05$. Three conclusions are as the result of the research. Firstly, there is a significant positive correlation between organizational climate and learning effectiveness with the correlation coefficient $R_{\mathbf{y} 1}=0.841$, and the determinant coefficient of $R_{\mathrm{y} 1}{ }^{2}=0.7068$. Secondly, there is a significant positive correlation between pedagogical competency with learning effectiveness with correlation coefficient of $R_{\mathbf{y} 2}=0.77$, and determinant coefficient of $R_{y 2}{ }^{2}=0.5997$. Thirdly, there is a highly significant positive correlation between organizational climate and pedagogical competency along with learning effectiveness with correlation coefficient of $R_{y .12}=0.886$ and determinant coefficient of $R_{y}{ }^{122}=0.785$. The research is considered as one of the applied examples for the current policy the so-called "Merdeka Belajar" which gives freedom for empowering the school environment including the competency of teachers.
\end{abstract}

Keywords-Merdeka Belajar, organizational climate, pedagogical competency

\section{INTRODUCTION}

Improving the quality of education has long been one of the national agenda priorities. However, a big gap is still there among areas in Indonesia although various forms of innovation and improvement efforts have been made to improve the quality and to overcome the problems at hand. It seems that efforts to improve and innovate so far have not been optimal in improving the quality of education and solving the problems. Another argument is that organizational climate and pedagogical competency seems not to be considered as important as other factors to impact learning effectiveness.

The results of the 2018 Program for International Student Assessment (PISA) study is one of the relevant indicators for explaining the continued gap in improving the quality of education. The 2018 PISA study, which were attended by 79 countries, showed that Indonesia's position with reading ability is in the $74^{\text {th }}$ position with an average score of 371 , mathematics ability is in the $7^{\text {th }}$ position from the bottom (73) with an average score of 379 , and the ability of science performance is ranked $9^{\text {th }}$ from the bottom (71) with an average score of 396. This is not much different from the 2015 PISA results, which were followed by 69 countries with score of 397 in reading skills, of 386 in math abilities, and of 403 in performance abilities science [1].

Education plays an important role in the process of improving the quality of human resources. This is in accordance with the Act No. 20 of 2003 concerned the National Education System which explains that [2]: "education is a conscious and deliberate effort to create an atmosphere of learning and the learning process so that learners are actively developing the potential for him to have the spiritual strength of religious, self-control, personality, intelligence, noble character, and skills needed by himself, society, nation and state". 
Minister of Education and Culture of the Republic of Indonesia, His Excellency Nadiem Anwar Makarim, has launched a policy the so-called "Merdeka Belajar" or Freedom of Learning. The policy is as a big reform to improve the quality of education in Indonesia. The policy is grounded to a principle that the establishment of education quality for the entire people of Indonesia will be realized if all stakeholders in education (including students) play their pivotal roles as change of agents and provide influence as well as fully support [3]. Stakeholders refer to families, teachers, institutions of education, business /industry, and communities.

The success of the policy of "Merdeka Belajar", is determined among others by teacher learning effectiveness. Teacher is a direct translator of existing curriculum. Teacher also deals directly with students. Teacher learning effectiveness increased not by itself, but as a process of conscious and planned to be improved both by teachers and by all the supporting factors such as peers, principals, department of education, as well as the parents and the students themselves [4]. In accordance with the policy of "Merdeka Belajar", teachers should pay attention to such main strategies. The main strategies include that learning is fun; that the cooperation among stakeholders should exist; that teacher acts as a facilitator in learning activities; that pedagogy is based on competency and values, curriculum and assessment; that employ such an approach based on individual needs and centered on student; and that teacher utilizes technology [3].

The effectiveness of learning is one of the benchmarks that can be used as a measuring tool to see whether the goals achieved have reached the maximum number or not [5]. A teacher in himself must have a high spirit of achievement that can be seen in learning activities. In supporting the effectiveness of learning, teachers must also be equipped with competencies. The problem of competence is a problem of teachers' behaviour and abilities; therefore, the competence of the teacher is actually oriented towards increasing the effectiveness of learning and ultimately leads to achievement as a teacher [6].

\section{A. Related Work}

1) Learning effectiveness: The effectiveness of learning is seen as the success of teacher to facilitate growth in an academic content area [7]. In relation to facilitating the growth of students, the effectiveness of learning is seen as the level or the degree where a problem or process succeeds in producing pleasant and expected results [8] by determining actions, choosing the right goals and methods for achievement the aim. In this case, aspects of the quality of teaching (quality of instruction), clarity (clarity), variations used by teachers (variety), directed to task orientation (task orientation), and allocation of time for teachers by the school and allocation of time for students to learn (time engagement) [6].

The effectiveness of learning is also seen as a collection of teacher characteristics, competencies, and behaviour that enable students to learn [9]. Some indicators that can measure the effectiveness of learning include: the interaction of positive student inside and outside the classroom, their rapid feedback, submission instructions are concrete, explicit, and attractive, positive relationships with students, time allotted on topics that are most relevant as learning objectives, higher order thinking skills, the use of various learning models for various learning styles, positive communication, attractive classroom environments, various teaching strategies, complementary teaching materials, and the use of evaluation-based assessments [5]. In addition, the effectiveness of learning can be influenced by personal factor, professional factors, intellectual factors; strategies of teaching ( teaching strategies ) such as techniques, selection of teaching methods in accordance with the character of different learners, student-centered approaches and setting group activities, social aspect [8], graciousness (elegance) include the attitude of a teacher-friendly, well prepared/organized (well prepared), collaborative, and charismatic $[10,11]$.

The effectiveness of learning can also be described as success in facilitating teaching that continues to be interesting and provides high perceptions and impacts in terms of psychomotor development, cognitive and affective domains of students [12]. This is certainly supported by several indicators, such as personality of teachers consisted of caring, kind, affectionate; subject matter expertise where teachers master teaching content; relational competence with students by having good interactions and recognizing student potential; professional competence which shows dedication and integrity; teaching style that is flexible, student-centered and uses a variety of teaching strategies; classroom management style to create a pleasant environment [13], preparation for teaching and planning (preparation and planning); interpersonal relations which includes the ability to establish good relationships with colleagues, students, and parents [14]. This presupposes the accuracy of the preparation of teaching programs, the management of good classroom conditions, the correct use of learning media and learning resources, the interaction between teachers and students, and the accuracy of the implementation of evaluation [15]. Factors that are thought to contribute to increasing the effectiveness of teacher learning include transformational leadership factors [16], organizational culture [17], organizational climate [18], principal leadership and teacher competence [6], pedagogical competency and teamwork [15] and organizational climate [19] which need to be improved as an effort to increase learning effectiveness.

In principle, the effectiveness of learning is the level of teachers' success in facilitating student growth in the psychomotor, cognitive, and affective domains to achieve optimal results, with measurement indicators in the form of (1) teacher characteristics (2) learning preparation (3) classroom management; (4) use of learning media; and (5) communication.

2) Organizational climate: Organizational climate reflects the perceptions held by members of the organization to their work environment [20], as an emotion, and behaviour by which the members of the organization can be revealed norms, 
values, and attitudes essential owned [21]. Organizational climate is also seen as a subjective perception of the objective environment, organizational conditions and nature of work, physical conditions and interpersonal relationships [22]. The organizational climate is formed by the support provided by members of the organization (support of organization) which is characterized by trust, openness, and good communication, supporting each other in work; positive interpersonal exchange where the academic community is seen as being together, forming a coherent whole and not experiencing significant conflict; environmental resources and time; security (safety) the confidence and assurance of safety, motivation; orientation on rewards, autonomy (autonomy/ independence) the freedom and flexibility to carry out the task; take risks (risk-taking) the courage to face the new situation which can provide inspiration in the work and; the pressure (stress) [23].

Organizational climate is also seen as the way people perceive (how people perceive) the culture in their organization which is reflected in several distinctive dimensions such as autonomy, the existence of trust and freedom of perception to communicate openly, performance standards, relationships. superiors and subordinates, recognition of members' contributions to the organization; justice and innovation, namely the organization encourages change [24], esprit of profession, organization and workgroup that shows a friendly atmosphere, leader facilitation and support as a friendly superiors attitude and provides an example by working hard, cohesion, clarity and objectivity of a system that shows a spirit of cooperation, job challenges, variety and feedback which includes high-level skills and training, the opportunity to make full use of knowledge and skills on the job [25].

Organizational climate also refers to the sociopsychological environment that influences members to participate and help [11] with the flexibility/ compatibility that emphasizes the aspects of new ideas received in the organization, the responsibility for which employees are the "owners" of the process. Which exists; specified work standards; Appreciation as the fact that their work is valued; Clarity of expectations from work; and work for the same goal [22]. In addition, the climate of an organization can be identified from several aspects such as the work environment that emphasizes the level of relationship between members, the assistance provided to employees, the existence of an organizational structure that measures the level of leadership and empowerment relationships, professional incentives that aim to establish the level of professional recognition of employees, professional security related to the risk of unreasonable dismissal, and a professional life that shows the level of professional identification of employees with the company [20,26]

In principle, organizational climate is an objective environmental condition, the nature of work and the work environment through which members of the organization can express norms, values and attitudes, with measurement indicators in the form of (1) cohesion, (2) warmth (friendliness), (3) leader support, (4) job challenges, and (5) autonomy.

3) Pedagogical competency: Pedagogical competency is the ability and skills of teachers related to teaching and learning interactions in the classroom [27,28]; the ability of teachers to manage students in teaching and learning process $[29,30]$ where teacher masters the characteristics of students, masters the principles of learning, masters curriculum development, masters typing in learning, masters the potential of students, and can carry out assessment methods [27]. Pedagogical competency can also be seen as a manifestation of the professionalism of teachers in their field and as the ability to develop learning plans and strategies to be applied in learning [31], as the ability and desire to apply attitudes, knowledge and expertise to promote, organize, evaluate and help students. to be able to actualize potential [32], through the development of sustainable teaching [33]. Pedagogical competency focuses on teacher teaching skills to develop the quality of the teaching and learning process through collaborative discussions [34]. Therefore, according to Chalil [35], the pedagogical competence of a teacher includes understanding educational insights or foundations, understanding students, developing curriculum/syllabus, learning design, implementing learning and dialogue, evaluating learning outcomes, and developing students.

Further elaboration of these indicators appears in several aspects such as preparation (preparation), presentation (presentation/conveying materials), method of learning (learning method), the characteristics of the teacher (teacher's characteristic), and closing (closing). Preparation includes lesson plans, the use of media, setting the students, and the materials that are tailored to the characteristics of students, the presentation is actually educate and dialogue include the teacher explaining, confirming and responding to students, use of teaching methods, the characteristics of the teacher can be seen from the attitude of assertiveness toward the learning situation, including the ability of teachers to conclude material and provide evaluations [34], use of learning technology, evaluation of learning outcomes, and development of students (able to grow students' personalities) [36]. Pedagogical competency is seen in several categories such as mastery of the characteristics of learners; mastery of learning theory, curriculum development, implementation of educational learning; utilization of ICT, facilitating the development of student potential, communication skills, ability to assess and evaluate affective, cognitive and psychomotor aspects , ability to utilize assessment and evaluation results, and categories of ability to take reflective action [28,30]. This requires awareness of the school in implementing the strategy for developing the pedagogical competence of teachers as developing teacher on a regular basis, involving teachers in the various scientific activities, improve the welfare of teachers and educational facilities, supervision of performance, and rewards for outstanding teachers [31,33]. 
In principle, pedagogical competency is the ability of a teacher to manage learning by applying attitudes, knowledge and skills as professional manifestations, with measurement indicators in the form of (1) curriculum development; (2) implementation of learning; (3) utilization of information and communication technology; (4) implementation of evaluation of learning outcomes; (5) mastery of student characteristics and (6) development of learners.

\section{Methodology}

This study aims to investigate the increase in the learning effectiveness. This research is a quantitative research using a survey method with correlational techniques and SITOREM (Scientific Identification Theory to Conduct Operation Research in Education Management) [37] with one dependent variable, namely the learning effectiveness variable (Y) and 2 independent variables, namely organizational climate. $\left(\mathrm{X}_{1}\right)$ and pedagogical competency $\left(\mathrm{X}_{2}\right)$. This study used 107 samples of civil servant teachers at SDN Tanah Sareal sub-district who were determined using a proportional random sampling technique. Data were collected using a questionnaire instrument consisting of (1) Learning Effectiveness questionnaire, consisting of 34 statement items filled out by the principal, with 5 measurement indicators in the form of; teacher characteristics, lesson preparation, classroom management, use of instructional media, and communication. (2) Organizational climate questionnaire consists of 33-point declaration filled out by teachers, with 5 indicators namely measurements; cohesion, warmth (friendliness), leader support, job challenges, and autonomy. 3) Pedagogical competency, consists of 33 statement items filled in by the teacher with 6 measurement indicators in the form of; curriculum development, implementation of learning, utilization of information communication technology, implementation of evaluation of learning outcomes, mastery of student characteristics and, student development. Instrument reliability level of learning effectiveness is of 0,86 , organizational climate of 0,85 , and pedagogical competency of 0,88 , using a scale of 1-5 (very good) to positive statements and 5-1 (excellent) to negative statements on all instruments. While SITOREM analysis is used to identify, analyse, assess and prioritize indicators of research variables that need to be fixed immediately or maintained by making expert judgment on the aspects of cost, benefit, urgency, and importance of each indicator [37].

\section{RESULTS AND DISCUSSION}

\section{A. Descriptive Statistical Results}

Based on Table 1, the lowest empirical score is 109 and the highest empirical score is 140 . The result of the calculation of the empirical median score is 124 . From these data, it can be said that the effectiveness of learning in the area of the study is in the good category, namely everything above the theoretical median value (upper $50 \%$ group), namely from the value of 125 to 140 . While the value range of 109 to 123 is in the poor category because it was below the median (lower $50 \%$ group). Organizational climate in the focus area of the study was included in the good category, namely everything that was above the theoretical median value (upper $50 \%$ group), namely from the value of 121 to 136 . \% down). Pedagogical competency in the focus area of the study is included in the good category, namely everything that is above the theoretical median value (upper $50 \%$ group), namely from the value of 30 to 34 . While the range of values 25 to 28 is in the poor category because it is below the median (group $50 \%$ down).

TABLE I. RESULT OF DESCRIPTIVE STATISTICS

\begin{tabular}{|c|l|l|l|}
\hline & $\begin{array}{c}\text { Learning } \\
\text { Effectiveness }\end{array}$ & $\begin{array}{c}\text { Organizational } \\
\text { Climate }\end{array}$ & $\begin{array}{l}\text { Pedagogical } \\
\text { Competency }\end{array}$ \\
\hline Mean & 124,18 & 120,18 & 29,46 \\
\hline $\begin{array}{c}\text { Standard } \\
\text { Error }\end{array}$ & 0,69 & 0,69 & 0,24 \\
\hline Median & 124 & 120 & 29 \\
\hline Mode & 127 & 122 & 30 \\
\hline $\begin{array}{c}\text { Standard } \\
\text { Deviation }\end{array}$ & 7,16 & 7,22 & 2,49 \\
\hline $\begin{array}{c}\text { Sample } \\
\text { Variance }\end{array}$ & 51,30 & 52,21 & 6,21 \\
\hline Range & 31 & 30 & 9 \\
\hline Minimum & 109 & 106 & 25 \\
\hline Maximum & 140 & 136 & 34 \\
\hline Sum & 13288 & 12860 & 3153 \\
\hline Count & 107 & 107 & 107 \\
\hline
\end{tabular}

\section{B. Testing Hypothesis Requirements}

Based on Table 2, the results of the calculation of the normality of the estimated standard error $\left(\mathrm{Y}-\hat{\mathrm{Y}}_{1}\right)$ for the learning effectiveness variable on organizational climate variables obtained a maximum $\mathrm{L}_{\text {count }}$ of 0.076 with $\mathrm{L}_{\text {table }}$ of 0.074 . The results of the calculation of the normality of the estimated standard error $\left(\mathrm{Y}-\hat{\mathrm{Y}}_{2}\right)$ of the learning effectiveness variable on the pedagogic competence variable obtained a maximum $\mathrm{L}_{\text {count }}$ of 0.055 with $\mathrm{L}_{\text {table }}$ of 0.086 at the significance level $\alpha=0.05$. It can be concluded that the data on the variable organizational climate, pedagogical competency and learning effectiveness, have a normally distributed population.

TABLE II. DATA NORMALITY TEST FOR X1, X2 AND Y USING THE LILIEFORS TEST

\begin{tabular}{|l|l|l|l|l|}
\hline No. & \multicolumn{1}{|c|}{$\begin{array}{c}\text { Estimated Default } \\
\text { Error }\end{array}$} & $\mathbf{L}_{\text {count }}$ & $\mathbf{L}_{\text {table }}$ & Conclusion \\
\hline 1 & $\mathrm{Y}-\hat{\mathrm{Y}}_{1}$ & 0.076 & 0.086 & $\begin{array}{l}\text { Normal } \\
\text { Distribution }\end{array}$ \\
\hline 2 & $\mathrm{Y}-\hat{\mathrm{Y}}_{2}$ & 0.055 & 0.086 & $\begin{array}{l}\text { Normal } \\
\text { Distribution }\end{array}$ \\
\hline \multicolumn{2}{|l|}{} \\
\hline \multicolumn{2}{|l|}{ Normal Terms: $\mathrm{L}_{\text {count }}<\mathrm{L}_{\text {table }}$ Liliefors $(\alpha=0.05)$} \\
\hline
\end{tabular}

Based on Table 3, homogeneity of variance variable data group learning effectiveness on variable organizational climate score obtained $\chi^{2}$ count amounted to 37.56 while $\chi_{\text {table }}^{2}(0.05)$ of 43.77. Homogeneity of variance group variable data Effectiveness of Education on variable pedagogical competency obtained score $\chi^{2}$ count amounted to 8.61 while $\chi_{\text {table }}^{2}$ 
$(\alpha=0.05)$ of 16.92 . In conclusion, the variance of the learning effectiveness variable on the organizational climate and pedagogical competency data score variants came from a homogeneous population.

TABLE III. SUMMARY OF HOMOGENEITY TEST FOR VARIABLE DATA GROUPS $\mathrm{X}_{1}, \mathrm{X}_{2}$ AND $\mathrm{Y}$

\begin{tabular}{|c|c|c|c|c|}
\hline No. & Group & $\chi^{2}$ count & $\chi^{2}$ table & Conclusion \\
\hline 1 & $\begin{array}{lll}\text { Variable } & \mathrm{Y} & \text { over } \\
\mathrm{X}_{1} & & \\
\end{array}$ & 37.56 & 43.77 & Homogeneous \\
\hline 2 & $\begin{array}{lll}\text { Variable } & \mathrm{Y} & \text { over } \\
\mathrm{X}_{2} & & \\
\end{array}$ & 8.61 & 16.92 & Homogeneous \\
\hline
\end{tabular}

\section{Hypothesis Test}

From the calculation results obtained a simple correlation coefficient $\left(r_{y 1}\right)$ of 0.841 which shows the relationship between the organizational climate variable and the learning effectiveness variable including a high level of relationship. Simple correlation significance testing was obtained by using the $t$ test and get the $t_{\text {arithmetic }}$ amounted to 29.38 , while the value of $t_{\text {table }}$ where $\mathrm{df}=105$, with a significance level $\alpha=0.05$ at 1.65 and at significance level $\alpha=0.01$ was obtained $t_{\text {table value of }}$ 2,36 , which means that the requirements of significance are met. The coefficient of determination $\left(\mathrm{R}_{\mathrm{y} 1}{ }^{2}\right)$ describes the contribution of the organizational climate variable that can affect the learning effectiveness variable. From the calculation results obtained a score of $\mathrm{R}_{\mathrm{y} 1}{ }^{2}$ equal to 0.7068 , which means that the organizational climate variable contributed $70,68 \%$ to the increase in the learning effectiveness variable. Thus it can be concluded that there is a very significant positive relationship with the strength of high relationship between organizational climate variables and learning effectiveness.

From the calculation results, a simple correlation coefficient $\left(\mathrm{r}_{\mathrm{y} 2}\right)$ of 0.77 shows high level relationship between pedagogical competency variable and learning effectiveness variable. The simple correlation significance test is obtained by using the $t_{\text {test }}$ and getting the $t_{\text {count }}$ of 19.83, while for the $t$ table value where $d k=105$ with a significance level of $\alpha=0.05$ of 1.6 5 and $\alpha=0.01$ of 2,36 which means the requirements of significance are met. The coefficient of determination $\mathrm{R}_{\mathrm{y} 2}{ }^{2}$ shows the magnitude of the contribution of the pedagogical competency variable which can affect the learning effectiveness variable. From the calculation results, it was obtained a score of $\mathrm{R}_{\mathrm{y} 2}{ }^{2}$ of 0.5997 , which means that the pedagogical competency variable contributed $59.97 \%$ to the increase in the learning effectiveness variable. Thus, it can be concluded that there is a very significant positive relationship with the strength of the high relationship between the pedagogical competency and the effectiveness of learning.

From the calculation results obtained a simple correlation coefficient $\left(\mathrm{r}_{\mathrm{y} .12}\right)$ of 0.886 and included in the high category. The multiple correlation significance test used the $F_{\text {test }}$ and resulted in an $F_{\text {count }}$ of 8.77, while the $F_{\text {table }}$ for $\mathrm{dk}_{\text {counters }}=2$ and $\mathrm{dk}_{\text {denominators }}=104$ at the significance level $\alpha=0.05$ at 3.08 and $\alpha=0.05$ at 4.81 , so that the requirements of the multiple correlation significance $F_{\text {count }}>F_{\text {table }}$ can be fulfilled. Score determinant coefficient between variable of organizational climate $\left(\mathrm{X}_{1}\right)$ and the pedagogical competency $\left(\mathrm{X}_{2}\right)$ together with the learning effectiveness $(\mathrm{Y})\left(\mathrm{R}_{\mathrm{y} .12^{2}}\right)$ of 0.785 which means that the variable of organizational climate and pedagogical competency collectively contributed $78.5 \%$ to the increase in learning effectiveness variable (See Figure 1).

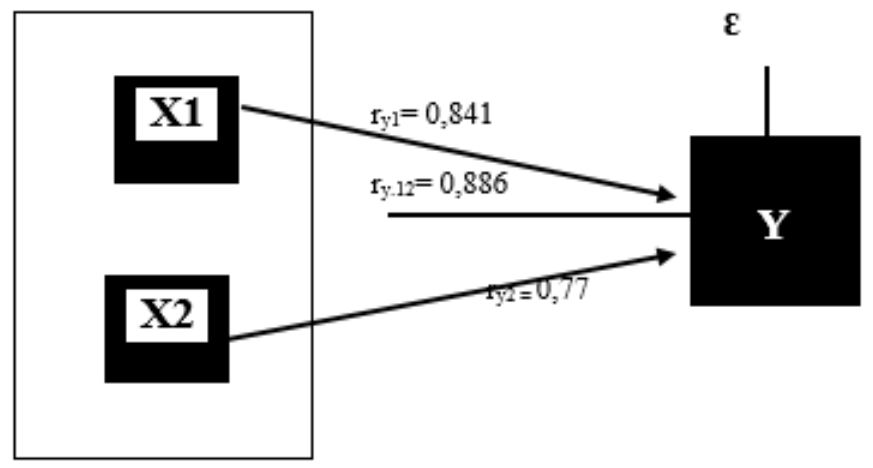

Fig. 1. Research constelation.

\section{Enhanced Priority Indicators}

Table 4 shows several indicators that need to be improved, (1) job challenges, (2) autonomy, (3) student characteristics, (4) evaluation of results, (5) curriculum development, (6) preparation, (7) learning media, and (8) teacher characteristics. While several indicators can be maintained as (1) leader support, (2) cohesion, (3) friendliness, (4) educating learning, (5) utilization of ICT, (6) student development, (7) communication, and (8) classroom management. 
TABLE IV. SITOREM ANALYSIS RESULTS

\begin{tabular}{|c|c|c|}
\hline \multicolumn{3}{|c|}{ Learning Effectiveness } \\
\hline Indicator in Initial State & Indicator After Weighting By expert & Value Indicator \\
\hline Teacher characteristics & $11^{\text {st }}$ Communication $(24 \%)$ & 4.00 \\
\hline Preparation & $2^{\text {nd }}$ classroom management $(24 \%)$ & 4.02 \\
\hline Class management & $3^{\text {rd }}$ Characteristics of teachers $(18 \%)$ & 3.39 \\
\hline Learning Media & $4{ }^{\text {th }}$ Learning media $(18 \%)$ & 3.34 \\
\hline Communication & $5^{\text {th }}$ Preparation $(16 \%)$ & 3.46 \\
\hline \multicolumn{3}{|c|}{ Organizational Climate $\left(\mathrm{r}_{\mathrm{y} 1}=0.841\right)$} \\
\hline Indicator in Initial State & \begin{tabular}{|c|c|} 
& Indicator After Weighting By expert \\
\end{tabular} & Value Indicator \\
\hline Cohesion & $11^{\text {st }}$ Leader support $(25 \%)$ & 4.01 \\
\hline Friendliness & $2^{\text {nd }}$ Cohesion $(21 \%)$ & 4.02 \\
\hline Leader support & $3^{\text {rd }}$ Autonomy $(19 \%)$ & 3.21 \\
\hline Job challenges & $4{ }^{\text {th }}$ Hospitality $(18 \%)$ & 4.00 \\
\hline Autonomy & $5^{\text {th }}$ Job challenge $(17 \%)$ & 3.04 \\
\hline \multicolumn{3}{|c|}{ Pedagogical Competency $\left(r_{\mathrm{y} 2}=0.77\right)$} \\
\hline Indicator in Initial State & \begin{tabular}{l|l} 
& Indicator After Weighting By expert \\
\end{tabular} & Value Indicator \\
\hline Curriculum Development & $1^{\text {st }}$ Teaching and Learning $(20 \%)$ & 0.90 \\
\hline Educating Learning & $2^{\text {nd }}$ Utilization of ICT (19\%) & 0.91 \\
\hline Utilization of ICT & $3^{\text {rd }}$ curriculum development $(16 \%)$ & 0.74 \\
\hline Results Evaluation & $4^{\text {th }}$ Evaluation of Results (16\%) & 0.75 \\
\hline Student Characteristics & $5^{\text {th }}$ Student development $(15 \%)$ & 0.91 \\
\hline Student development & $6{ }^{\text {th }}$ Student Characteristics $(14 \%)$ & 0.78 \\
\hline Maintained priority indicators & \multicolumn{2}{|c|}{ Enhanced priority indicators } \\
\hline $1^{\text {st }}$ Leader support & \multicolumn{2}{|l|}{$1^{\text {st }}$ Job challenge } \\
\hline $2^{\text {nd }}$ Cohesion & \multicolumn{2}{|l|}{$2^{\text {nd }}$ Autonomy } \\
\hline $3^{\text {rd }}$ hospitality & \multicolumn{2}{|l|}{$3^{\text {rd }}$ Student Characteristics } \\
\hline $4^{\text {th }}$ Educating Learning & \multicolumn{2}{|l|}{$4^{\text {th }}$ Evaluation of Results } \\
\hline $5^{\text {th }}$ Use of ICT & \multicolumn{2}{|l|}{$5^{\text {th }}$ Curriculum Development } \\
\hline $6^{\text {th }}$ Student development & \multicolumn{2}{|l|}{$6^{\text {th }}$ Preparation } \\
\hline $7^{\text {th }}$ Communication & \multicolumn{2}{|l|}{$7^{\text {th }}$ Learning media } \\
\hline $8^{\text {th }}$ Class Management & \multicolumn{2}{|l|}{$8^{\text {th }}$ Teacher characteristics } \\
\hline
\end{tabular}

Correlation coefficient between organizational climate and learning effectiveness, including the strength of the relationship that is high $\left(\mathrm{r}_{\mathrm{y} 1}=0.841\right)$ with a significance level of 29.38 (very significant), whose downloading indicate there is a significant positive relationship between the variables of organizational climate and learning effectiveness. Organizational climate describes the state of an organization. A good organizational climate will provide mutual support needed by members of the organization which is characterized by trust, openness, a sense of humour, and good communication, supporting each other in work so as to increase teacher success in facilitating student growth in the psychomotor, cognitive, and affective domains. The organizational climate will create a friendly and comfortable atmosphere, relationships based on trust and openness and the creation of conditions conducive to development, thus helping to control classroom management and the formation of good communication. The organizational climate will form a coherent unity and will not experience significant conflicts that can hinder the effectiveness of learning. A good organizational climate will increase the effectiveness of learning by showing respect for students' different backgrounds, ideologies, beliefs, and learning styles. This research supports previous research conducted by Thomas and Oladipo [19], entitled "Organizational Climate And Employees' Effectiveness In Lagos State Education Districts." in the Proceedings of ISER $158^{\text {th }}$ International Conference, Ottawa, Canada shows a positive and significant relationship between organizational climate and learning effectiveness by calculating the value of $r=0.090$ which is greater than the critical $r$ value of 0.088 at the 0.05 significance level and the 478 level of freedom. A research conducted by Alam [11] entitled "Study Of Organizational Climate In Relationships To Teacher Effectiveness" in the International Journal of Informative and Futuristic Research (IJIFR) shows a positive and significant relationship between Organizational Climate and Learning Effectiveness $(r=0.619 ; \mathrm{p}<.05)$. All of these relevant studies provide the same conclusion, that there is a very significant positive relationship between organizational climate and learning effectiveness.

Correlation coefficient between pedagogical competency and learning effectiveness, including the strength of the relationships that high $\left(\mathrm{r}_{\mathrm{y} 2}=0.77\right)$ with a significance level of 19.83 (very significant). Teachers who have good pedagogical competence reflect an understanding of the material, concepts, principles being taught. When the teacher has a good understanding of the material and learning concepts that will be carried out, the teacher is easier to channel it to students and of course with a good understanding of theory, the teacher will find it easier to choose teaching methods and techniques that are in accordance with the characteristics of students.

In the domain of learning planning, teacher competency does not only contain knowledge of the content of teaching material, but also comprehends students' abilities, planning 
learning, resources, designing learning processes and designing learning outcome assessment processes. Pedagogical competency includes how to understand students in depth, design learning, understanding the educational foundation for the benefit of learning, implementing learning, designing and implementing learning evaluations, developing students to actualize their various potentials will lead to the creation of effective learning. This happens because the teacher has from the beginning determined the variables that can increase student enthusiasm for learning.

This study supports previous research conducted by Banani [6], with the title "The Effect of Principal Leadership on Teacher Competence in Realizing Learning Effectiveness" in the Education Journal of the University of Garut, obtained $t_{\text {count }}$ 4.8039> $\mathrm{t}_{\text {table }} 1.9977$, which means that there is a significant influence of the teacher competency variable on the learning effectiveness. In addition, research conducted by Fathurrahman [15], with the title "Increasing Learning Effectiveness through Increasing Pedagogical Competence and Teamwork" in the Journal of Educational Management. The results of the correlation test show that the correlation coefficient between pedagogic competence and learning effectiveness $\left(\mathrm{r}_{\mathrm{y} 1}\right)$ is 0.201 . The probability value is $0.029<0.05$, which indicates that the correlation coefficient is significant. All of these relevant studies provide the same conclusion, namely that there is a significant positive relationship between teacher pedagogical competence and learning effectiveness.

The correlation coefficient of the relationship between organizational climate and teacher pedagogical competency together on learning effectiveness is included in the high strength of the relationship $\left(r_{y .12}=0.886\right)$ with a significance level of 8.77 (very significant). Thus, the results of this study indicate that there is a significant positive relationship with a high strength relationship between organizational climate variables and teacher pedagogical competency together with learning effectiveness. Based on the discussion of the research results above, it can be concluded that there is a very significant positive relationship with a high strength of the relationship between organizational climate variables and pedagogical competence together with learning effectiveness, which means that the higher the organizational climate and pedagogical competency together, the higher the learning effectiveness shown by the ASN teacher.

Thus, teachers in the research area are assumed to understand how to develop effective learning characterized by gracious teacher personalities such as friendly, cooperative, supportive, sincere, polite, kind, honest, have a sense of humour, empathy, dedication to work, and have an attitude of tolerance. Teachers need to be well prepared / organized, such as planning lessons, being active, on time, delivering subject matter effectively, and being innovative. The collaborative aspect presupposes good, interactive teacher communication skills, becomes a role model, responds to student questions politely and well, encourages and motivates student participation in all learning activities, increases student selfconfidence, uses examples that can be understood and are in accordance with the realities of life students, aware of the level of understanding of students, good teaching skills, by avoiding non-professional attitudes such as conversations that are irrelevant to the material or conversations that are personal [10] in the subject matter expertise in which the teacher must have knowledge of the subject matter, provide well-prepared lessons, and master teaching content, have relational competence with students where the teacher has the ability to build and maintain relationships in harmonious, open-minded, accepting ideas and opinions of students, have a good interaction with the students, has a teaching style that is flexible, student-centered, use a variety of teaching strategies, management skills class (classroom management style) that models positive behaviour, always maintaining discipline, appreciating good behaviour, and creating a safe environment for the continuity of learning [13].

In addition, teachers need to know how to develop an organizational climate characterized by support of organization characterized by trust, openness and good reciprocal communication, mutual support for each other at work, positive interpersonal exchanges. Where schools are seen as 'being together' places, forming a coherent whole and not experiencing significant conflict. In addition, there is safety where all members feel that they can openly talk about new ideas and will not be intimidated or cornered, and trust and safety guarantees are a priority. Teachers are given autonomy (Autonomy/independence) in which there is freedom and flexibility to carry out their duties and the courage of the teacher to face new situations that can inspire work [23]. A positive organizational climate will be created with the existence of trust, namely the trust given by the organization to every teacher to achieve the school's vision and mission. Teachers are given the opportunity to make full use of knowledge and skills in their work, variations in assignments given by schools, and opportunities to do a number of different things in activities and assignments [25]

Teachers in the research area are assumed to understand how to develop pedagogical competences characterized by the understanding of educational insights and foundations by the teacher (understand and can apply educational foundations both philosophical, psychological, sociological, and so on); understanding of students in all its aspects (including identification of potential, characteristics, initial abilities, and difficulties of students, understanding and being able to apply learning theory according to the level of development of students); curriculum/syllabus development that is tailored to the context of students, the use of thematic methods; there is learning planning by identifying variables that can increase students' interest in learning; the use of learning technology that can facilitate understanding and more actual and relevant learning resources; the development of students (able to grow the personality of students) [36]; the ability to assess and evaluate the affective, cognitive and psychomotor aspects of students and aspects of assessment in the form of results and effects of learning activities; the ability to take advantage of assessment and evaluation results such as remedial programs and; there is a category of ability to carry out reflective actions 
such as deliberations, discussions and meetings across schools and classroom action research [30].

\section{CONCLUSION}

Learning effectiveness can be increased through organizational climate and pedagogical competency, either separately or collectively. It was found that there was a very significant positive relationship with a high strength relationship between organizational climate variables and learning effectiveness, there was a very significant positive relationship with a high strength relationship between pedagogical competency and learning effectiveness, and there was a very significant positive relationship with the strength of the relationship. High between the variable of organizational climate $\left(\mathrm{X}_{1}\right)$ and pedagogical competency $\left(\mathrm{X}_{2}\right)$ together with the learning effectiveness (Y).

From the results of the SITOREM analysis, several indicators need to be improved, namely (1) job challenges, (2) autonomy, (3) student characteristics, (4) evaluation of results, (5) curriculum development, (6) preparation, (7) learning media, and (8) teacher characteristics. While several indicators can be maintained including (1) leader support, (2) cohesion, (3) friendliness, (4) educating learning, (5) utilization of ICT, (6) Student development, (7) communication, and (8) classroom management.

\section{REFERENCES}

[1] A. Schleicher, "PISA (Programme for International Student Assessment) 2018 Insights and Interpretations," 2018.

[2] Munirah, "Sistem Pendidikan Di Indonesia: Antara Keinginan Dan Realita," AULADUNA, vol. 2, no. 36, pp. 233-245, 2015.

[3] Naim, “Kebijakan Pendidikan Nasional 2020-2024," Jakarta, 2020.

[4] Hendarman and Rohanim, Kepala Sekolah Sebagai Manajer; Teori dan Praktik. Bandung: Rosdakarya, 2018.

[5] A. Paolini, "Enhancing Teaching Effectiveness and Student Learning Outcomes," J. Eff. Teach. an online J. devoted to Teach. Excell. Enhancing, vol. 15, no. 1, pp. 20-33, 2015.

[6] M.T. Banani, "Pengaruh Kepemimpinan Kepala Sekolah terhadap Kompetensi Guru dalam Mewujudkan Efektivitas Pembelajaran," J. Pendidik. Univ. Garut, vol. 11, no. 01, pp. 67-76, 2017.

[7] L.E. Sandilos, W.A. Sims, K.E. Norwalk, and L.A. Reddy, "Converging on quality: Examining multiple measures of teaching effectiveness," J. Sch. Psychol., vol. 74, no. April, pp. 10-28, 2019.

[8] R.R. Roy and U.K. Halder, "Teacher Effectiveness: A Self-Report Study on Secondary School Teachers Teacher Effectiveness," IJRAR- Int. J Res. Anal. Rev., vol. 5, no. September, pp. 914-919, 2018.

[9] U. Dash and P. Barman, "Teaching Effectiveness of Secondary School Teachers in the District of Purba Teaching Effectiveness of Secondary School Teachers in the District of Purba Medinipur,West Bengal," IOSR J. Humanit. Soc. Sci., vol. 21, no. 7, 2018.

[10] S.S. Batool, B. Naz, S. Habib, W. Anjum, F. Goraya, M. Akram, ... and A. Sadaf, "Construction of Effective Teaching Evaluation Scale and Students' Perception of the Characteristics of Effective Teachers,' Pakistan J. Soc. Clin. Psychol., vol. 13, no. 1, pp. 28-35, 2015.

[11] M. Alam, "Study Of Organizational Climate In Relation To Teacher Effectiveness,” Int. J. Inf. Futur. Res., vol. 6, no. 3, pp. 18-29, 2018.
[12] M. Zairi, A. Hasan, N. Bahiyah, A. Wahab, and J. Jantan, "Determining Teaching Effectiveness for Physical Education Teacher," Procedia - Soc. Behav. Sci., vol. 172, pp. 733-740, 2015.

[13] G.M. Calaguas, "Teacher effectiveness scale in higher education Development and psychometric properties," Int. J. Res. Stud. Educ., vol. 2, no. 2, pp. 3-20, 2013.

[14] J. Swargiary and N. Baglari, "A Study on Teacher Effectiveness at Primary Level,” IOSR J. Humanit. Soc. Sci., vol. 23, no. 1, pp. 28-35, 2018.

[15] A. Fathurrahman, Sumardi, A.E. Yusuf, and S. Harijanto, "Peningkatan Efektivtas Pembelajaran Melalui Peningkatan Kompetensi Pedagogik Dan Teamwork," J. Manaj. Pendidik., vol. 7, no. 2, pp. 843-850, 2019.

[16] A. Setiawan, "Kontribusi kepemimpinan transformasional kepala sekolah dan iklim sekolah terhadap efektivitas sekolah," J. Adm. Pendidik., vol. XXIII, no. 1, pp. 130-140, 2016.

[17] M.H.H. Yusuf, "Pengembangan Budaya Organisasi Dalam Lembaga Pendidikan," J. Tarbawi, vol. 14, no. 1, 2017.

[18] A.D. Alexander and A.R. Chukwudi, "Emotional Intelligence and Teacher Efficacy as Predictors of Teacher Effectiveness among PreService Teachers in Some Nigerian Universities," Int. J. Eval. Res. Educ., vol. 3, no. 2, 2014

[19] O. Thomas and S. Oladipo, “Organisational Climate And Employees' Effectiveness In Lagos State Education Districts," in Proceedings of ISER 158th International Conference, Ottawa, Canada, 2018, no. September, pp. 55-60.

[20] C.Z. Kirilo, J.M. Abe, L.A. de Lima, L.C.M. Lozano, M. Nogueira, C.C. de Oliveira, and K. Nakamatsu, "Organizational climate assessmen using the paraconsistent decision method," Procedia Comput. Sci., vol. 131, pp. 608-618, 2018

[21] H. Hashim, N.A. Ishak, and Z.A.G. Hilmi, "Influence of Organizational Climate on Disabled Job Embeddedness," Procedia - Soc. Behav. Sci. vol. 202, no. December 2014, pp. 242-251, 2015.

[22] Ö. Akbaba and E. Altındağ, "The Effects Of Reengineering, Organizational Climate And Psychological Capital On The Firm Performance," Procedia - Soc. Behav. Sci., vol. 235, no. October, pp. $320-331,2016$

[23] A. Sokol, A. Gozdek, I. Figurska, and M. Blaskova, "Organizationa climate of higher education institutions and its implications for the development of creativity," Procedia - Soc. Behav. Sci., vol. 182, pp. 279-288, 2015

[24] S. Armstrong, Armstrong's Handbook of Human Resource Management Practice, Twelfth ed. United Kingdom: koganpage, 2012.

[25] A. Datta and R. Singh, "Determining the dimensions of organizational climate perceived by the hotel employees," J. Hosp. Tour. Manag., vol. 36, no. February, pp. 40-48, 2018.

[26] Hendarman, Revolusi Kinerja Kepala Sekolah. Jakarta: Indeks, 2019.

[27] Jumardin, “Analisis Kompetensi Pedagogik dan Kompetensi Profesiona Dosen Ditinjau dari Tingkat Pendidikan," Indones. J. Learn. Educ. Couns., vol. 1, no. 1, pp. 76-84, 2018

[28] D.P. Safitri, D. Ariani, and Khaerudin, "Evaluasi Kompetensi Pedagogik Guru Pasca Pelatihan Guru Pembelajar Moda Daring," J. Pembelajaran Inov., vol. 1, no. 1, pp. 33-36, 2018.

[29] J. Musfah, Peningkatan Kompetensi Guru Melalui Pelatihan dan Sumber Belajar Teori dan Praktik. Jakarta: Kencana, 2011.

[30] N. Sumiarsi, "Analisis Kompetensi Pedagogik dan Pengembangan Pembelajaran Guru SD Negeri 041 Tarakan,” J. Kebijak. dan Pengemb. Pendidik., vol. 3, no. 1, pp. 99-104, 2015.

[31] L. Hakim, "Development strategy of pedagogical competence improve professionalism of islamic education teacher," J. Pendidik. Islam, vol. 3 , no. 2, pp. 207-220, 2017.

[32] B.P.A. Tyagita and A. Iriani, "Strategi Peningkatan Kompetens Pedagogik Guru Untuk Meningkatkan Mutu Sekolah,” J. Manaj. Pendidik., vol. 5, no. 02, pp. 165-176, 2018. 
[33] A. Puspitasari, M. Anugerahwati, and S. Rachmajanti, "Teachers Pedagogical and Professional Competences in CLIL-Based Primary Schools in Indonesian Context," in Education in the 21th Century: Responding to Current Issues, 2016, pp. 105-115.

[34] S. Aimah, M. Ifadah, and D.A.L. Bharati, "Building Teacher's Pedagogical Competence and Teaching Improvement through Lesson Study,” Arab World English J., vol. 8, no. 1, pp. 66-78, 2017.
[35] A. Chalil, Pembelajaran Berbasis Fitrah/Achjar Chalil dan Hudaya Latuconsina. Jakarta: Balai pustaka, 2008.

[36] S. Alkornia, "Studi Deskriptif Kompetensi Pedagogik Dan Profesionalisme Guru Paud Dharma Wanita Binaan SKB Situbondo," Pancaran, vol. 5, no. 4, pp. 143-158, 2016.

[37] S. Hardhienata, "The Development of Scientific Identification Theory to Conduct Operation Research in Education Management," Manag. IOP Conf. Ser. Mater. Sci. Eng., vol. 166, 2017. 